\title{
Large intact forest landscapes and inclusive conservation: a political ecological perspective
}

\author{
Laura Zanotti ${ }^{1}$ \\ Natalie Knowles \\ Purdue University, USA \\ University of Waterloo, Canada
}

\begin{abstract}
Intact Forest Landscapes (IFLs) are global conservation units that aim to combat fragmentation, alteration, degradation, and loss of global forests. ILFs are typically recognized for their biodiversity, carbon storage, protection of hydroecological systems and other ecosystem services. However, IFLs are distinctive among other conservation efforts because they do not immediately prioritize conservation approaches that have goals of alleviating human poverty or improving well-being. The prevailing view is that IFL conservation should engage with ecocentric models of conservation. In this article, we leverage political ecology's analytical attention to power, institutions, identities, and scales to make suggestions on ways in which to integrate biocentric conservation considerations into IFL practices. From a scoping literature review, we found the following areas are especially critical for the future of IFL conservation: (1) prioritizing Indigenous Peoples and Local Communities (IPLC) as actors and beneficiaries of conservation; (2) identifying the value of knowledge integration and co-production for conservation; (3) addressing heterogenous communities and equity impacts, and (4) the need for procedural mechanisms in conservation initiatives that support nesting Indigenous Peoples and Local Communities management and governance in polycentric systems. Furthermore, the development of diagnostic questions of scaling community-based conservation and adaptive strategies beyond their original scope in terms of community definitions, landscape and political context may be beneficial for addressing multistakeholder needs, identifying more equitable approaches, sharing strategies and obtaining successful outcomes in IFL conservation.
\end{abstract}

Keywords: Indigenous peoples and local communities, large intact landscapes, forests, conservation

\section{Résumé}

Intact Forest Landscapes (IFL) sont des unités de conservation mondiales qui visent à lutter contre la fragmentation, l'altération, la dégradation et la perte des forêts mondiales. Les IFL sont généralement reconnus pour leur biodiversité, le stockage du carbone, la protection des systèmes hydroécologies et d'autres services écosystémiques. Cependant, les IFL se distinguent des autres efforts de conservation car ils ne donnent pas immédiatement la priorité aux approches de conservation qui ont pour but de réduire la pauvreté humaine ou d'améliorer le bien-être. L'opinion dominante est que la conservation des IFL devrait s'engager dans des modèles de conservation égocentriques. Dans cet article, nous tirons parti de l'attention analytique portée par l'écologie politique au pouvoir, aux institutions, aux identités et aux échelles pour faire des suggestions sur la manière d'intégrer les approches biocentriques et les valeurs relationnelles dans les pratiques des IFL. Une revue de la littérature nous a permis de constater que les domaines suivants sont particulièrement critiques pour l'avenir de la conservation de l'IFL: (1) prioriser les populations autochtones et les communautés locales en tant qu'acteurs et bénéficiaires de la conservation; (2) identifier la valeur de l'intégration et de la coproduction des connaissances pour la conservation; (3) traiter les communautés hétérogènes et les impacts sur l'équité, et (4) le

\footnotetext{
${ }^{1}$ Dr. Laura Zanotti, Associate Professor, Department of Anthropology, Purdue University, West Lafayette, Indiana 47907, USA. Email: lzanotti "at" purdue.edu. Natalie Knowles, PhD student, Geography and Environmental Management (GEM), University of Waterloo, Canada. Email: nlbknowles "at" uwaterloo.ca. Acknowledgements: We would like to thank colleagues who gave us critical input throughout the writing of this article. We would also like to thank JPE referees for their work and thoughtful feedback.
} 
besoin de mécanismes procéduraux dans les initiatives de conservation qui soutiennent la gestion et la gouvernance des populations autochtones et des communautés locales (IPLC) dans les systèmes polycentriques. En outre, l'élaboration de questions diagnostiques sur la mise à l'échelle de la conservation communautaire et des stratégies d'adaptation au-delà de leur portée initiale en termes de définitions communautaires, de paysage et de contexte politique peut être bénéfique pour répondre aux besoins de plusieurs parties prenantes, identifier des approches plus équitables, partager des stratégies et obtenir des résultats fructueux dans la conservation des LIF.

Mots-clés: Peuples autochtones et communautés locales, grands paysages intacts, forêts, conservation

\section{Resumen}

Los Paisajes Forestales Intactos (IFL, por sus siglas en inglés) son unidades de conservación global que tienen como objetivo combatir la fragmentación, la alteración, la degradación y la pérdida de los bosques mundiales. Los ILF suelen ser reconocidos por su biodiversidad, almacenamiento de carbono, la protección de sistemas hidroecológicos y otros servicios al ecosistema. Sin embargo, los IFL se distinguen entre otros esfuerzos de conservación porque no priorizan de inmediato los enfoques de conservación que tienen como objetivos aliviar la pobreza humana o mejorar el bienestar. La opinión predominante es que la conservación de los IFL debería involucrarse con modelos ecocéntricos de conservación. En este artículo, aprovechamos la atención analítica de la ecología política al poder, las instituciones, las identidades y las escalas para hacer sugerencias sobre formas de integrar enfoques biocéntricos y valores relacionales en las prácticas de los IFL. De una revisión inicial de la literatura, encontramos las siguientes áreas son especialmente críticas para el futuro de la conservación de los IFL: (1) priorizar a los pueblos indígenas y las comunidades locales como actores y beneficiarios de la conservación; (2) identificar el valor de la integración del conocimiento y la coproducción para la conservación; (3) abordar las comunidades heterogéneas y los impactos de equidad, y (4) la necesidad de mecanismos de procedimiento en iniciativas de conservación que apoyen la gestión y gobernanza de los Pueblos Indígenas y Comunidades Locales (IPLC, por sus siglas en inglés) en sistemas policéntricos. Además, el desarrollo de preguntas de diagnóstico para ampliar la conservación basada en la comunidad y las estrategias adaptativas más allá de su alcance original en términos de definiciones comunitarias, paisaje y contexto político puede ser beneficioso para abordar las necesidades de múltiples partes interesadas, identificar enfoques más equitativos, compartir estrategias y obtener resultados exitosos resultados en la conservación de los IFL.

Keywords: Pueblos indígenas y comunidades locales, grandes paisajes intactos, bosques, conservación

\section{Introduction}

Intact Forest Landscapes (IFLs) are global conservation units that aim to combat fragmentation, alteration, degradation, and loss of global forests (Watson et al. 2018). IFLs can be defined as those landscapes that are "a seamless mosaic of forest and naturally treeless ecosystems" with "limited human activity and a minimum area of $500 \mathrm{~km}^{2}$ " (Potapov et al. 2017: 1). They are typically designed to meet several conservation objectives and recognized for their biodiversity, carbon storage, protection of hydroecological systems and other ecosystem services (Intact, nd). However, IFLs are distinctive among other conservation efforts because they do not immediately prioritize conservation approaches that have goals of alleviating human poverty or improving well-being. The prevailing view is that IFL conservation should engage with ecocentric models of conservation (Caillon et al. 2017). Yet, IFLs provide an especially promising arena in which to explore the role of other approaches to conservation.

Transforming degraded or fragmented landscapes to "intactness" is difficult and takes considerable time, suggesting that the one way to retain the "full range" of conservation values of an intact landscape is to support the communities that maintain intactness (Potapov et al. 2008: 62; Potapov et al. 2017). In this article, we leverage political ecology's analytical attention on power, institutions, identities, and scales to make suggestions on ways to integrate biocentric and relational conservation considerations into IFL practices. The goal is to identify key dimensions of conservation models that should be prioritized for the IFL conservation. To do so, we evaluate the successes, failures, and challenges of both theoretical approaches to conservation initiatives as well as cases studies of community-based approaches in already existing IFL initiatives. Through an analysis 
of case studies derived from a scoping literature review, we found the following areas are especially critical for the future of IFL conservation:

(1) prioritizing Indigenous Peoples and Local Communities (IPLC) as actors and beneficiaries of conservation;

(2) identifying the value of knowledge integration and co-production for conservation design (Kaplan-Hallam and Bennett 2018);

(3) addressing heterogenous communities, a good life, rights, and equity, and

(4) the need for procedural mechanisms in conservation initiatives that support nesting Indigenous Peoples and Local Communities in the management and governance in polycentric systems (e.g. see Ostrom 2010).

\section{Calculating value}

In environmental policy making, the conservation value of an ecosystem is normally calculated by considering the function of both quality and quantity. For example, intact landscapes are defined as unbroken expanses of natural ecosystems showing no signs of significant disturbance that are greater that $500 \mathrm{~km}^{2}$, at least "10 km wide at the broadest place" and "2 km wide in corridors" (Potapov et al. 2008: 53). The desert and Arctic tundra regions, the boreal forest in Canada and Russia, and moist tropical forests in the Amazon Basin and central Africa are some of the last remaining large tracts of forest landscapes (Birdsey and Pan 2015: 87; Sanderson et al. 2002). As Wyborn and Bixler (2013: 65) suggest, "large-scale conservation grew from a belief that the spatial scale of current conservation action is mismatched with the scale of ecological processes and broader drivers of land-use change" (also see Betts et al. 2017). Thus, one of the assumptions behind IFLs is that they have greater ability to meet conservation goals. Based on size alone, IFLs encompass the biodiversity of a biome including a variety of species to maintain ecological processes and services better than conservation units at smaller scales (Betts et al. 2017; Brosius and Russell 2003; Potapov et al. 2008). Supporting and encompassing entire ecological processes and higher biodiversity levels means large intact areas may have greater resistance and resilience to disturbances including climate change and will continue to provide resources for sustaining life (Betts et al. 2017; Heino et al. 2015; Potapov et al. 2008).

Intact forest landscapes, including tropical, temperate, and boreal forests, provide important habitat to numerous plant and animal species (Potapov et al. 2008). Forests are considered especially important, because these provide necessary provisional (timber, non-timber forest products) and supporting (e.g. water purification) ecosystem services at both a regional and global scale (Potapov et al. 2008). Forest landscapes also are the greatest terrestrial carbon sinks, crucially mitigating climate change rates by storing carbon (Birdsey and Pan 2015; Potapov et al. 2008). In 2000, 65 countries supported IFLs, with Russia, Brazil and Canada holding nearly $60 \%$ of global IFLs (Heino et al. 2015; Potapov et al. 2017). Tropical intact forest landscapes alone store $97 \mathrm{Gt}$ of carbon, but between 2000 and 2016 there was a 7.2\% loss in intact forestland and $60 \%$ of this came from tropical areas, particularly South America (Heino et al. 2015; Potapov et al. 2017: 2). In addition, 19\% of remaining tropical forests now lie within 100 meters of a forest edge, which has "caused an additional $10.3 \mathrm{Gt}$ of carbon emissions" or "8.5\% of overall annual atmospheric carbon gains" (Brinck et al. 2017: 2-4; also see Heino et al. 2015). Fragmentation or loss of intact landscapes is primarily a result of industrial resource extraction (mining and logging), agricultural expansion and urban development (Heino et al. 2015; Potapov et al. 2017). At current rates, according to Potapov et al. (2017: 2), "Paraguay, Laos, Cambodia, and Equatorial Guinea will lose their entire IFL area during the next 20 years", while by 2077 IFLs will only remain in 45 countries. The rate of fragmentation and deforestation has led some practitioners and policymakers to favor ecocentric approaches to IFLs to more rapidly meet conservation goals. By ecocentric models we refer those approaches that prioritize preserving nature for nature's sake (intrinsic values) most exemplified in fortress conservation paradigms which assume that exclusion of human impacts from protected spaces enhances conservation goals (Vaccaro, Beltran and Paquet 2013). However, in the broader conservation community biocentric and increasingly relational, not ecocentric, models have been the trending norm (Chan et al. 2016). 
As opposed to ecocentric models, biocentric approaches to conservation consider the interrelationships between ecosystems and well-being, and relational approaches consider the "ecological conditions ensuring the preservation of life on Earth, the social conditions for maintaining harmonic human-nature relationships (e.g., sacred and cultural values), or the experiences and entities necessary for cultivating the notion of a 'good' life" (Arias-Arévalo et al. 2017: 44). These models to conservation include approaches where the historical relationship IPLCs had or have with conservation-designated landscapes are acknowledged, the value of IPLC knowledges and lifeways for the management and stewardship of landscapes are recognized, conservation and poverty alleviation is approached as coupled, and in recent years, the relationships between conservation, wellbeing, and a good life are considered interlinked (Caillon et al. 2017; Chan et al. 2016) (See Table 1). Theoretically, biocentric and relational approaches are addressed by frameworks such as sustainability science, socio-ecological systems, common pool design principles, and political ecology. These frameworks move away from considering human disturbances and impacts as drivers of environmental change toward approaching socionatural relationships as interlocking and co-produced (Büscher and Fletcher 2020; Cote and Nightingale 2012).

Methodologies that reflect biocentric and increasingly relational approaches include communitycentered approaches (e.g. community-based conservation, participatory development, co-management), crowdsourced solutions (citizen science), and mixed methods approaches with multiple stakeholders or rights-holders (multi-, inter-, and trans-disciplinary work) (e.g. Campbell and Vainio Mattila 2003). In this way, these approaches tend to share the following five assumptions as they have shaped the conservation landscape over the past three decades:

(1) an increase in diverse perspectives and actors involved in the conservation process will better help co-produce strategies that meet conservation goals;

(2) community and individual participation in decision-making around the formulation and enactment of conservation goals and governance will enhance contributions to and investment in conservation programs (e.g. see Berkes 2007);

(3) conservation programs should engage with and learn from IPLCs and their knowledge systems;

(4) humans can not only drive but also can enhance conservation efforts and initiatives (Diaz et al. 2015; Kareiva and Marvier 2012); and

(5) conservation outcomes should improve healthy environments and promote a good life (Brondizio and Le Tourneau 2016; Tengö et al. 2017).

\begin{tabular}{cc}
\hline ECOCENTRIC APPROACHES & BIOCENTRIC APPROACHES \\
\hline $\begin{array}{c}\text { Blame local users as drivers of environmental } \\
\text { degradation and suggest their knowledge } \\
\text { systems are deficient }\end{array}$ & $\begin{array}{c}\text { View IPLCs as actors and beneficiaries of conservation } \\
\text { and recognize the value of their knowledge in the co- } \\
\text { production of conservation }\end{array}$ \\
\hline $\begin{array}{c}\text { Prioritize centralized governance and limit local } \\
\text { user involvement in the management and } \\
\text { stewardship of conservation resources }\end{array}$ & $\begin{array}{c}\text { Recognize the need for procedural mechanisms in } \\
\text { conservation initiatives that support nesting IPLC } \\
\text { management and governance in polycentric systems }\end{array}$ \\
\hline $\begin{array}{c}\text { View environmental "subjects" as largely } \\
\text { homogenous rational actors. }\end{array}$ & $\begin{array}{c}\text { Adopt an intersectional analysis of individuals and } \\
\text { communities to address equity and rights at multiple }\end{array}$ \\
\end{tabular}

Table 1: Ecocentric versus biocentric approaches to conservation.

There are some hurdles to adopting newer approaches to conservation, which may, in part, explain the hesitation to apply them widely in IFLs. While IPLC involvement is increasingly acknowledged as a necessary 
condition for successful conservation to take place, their rights, and the pursuit of justice have continued to remain sidelined or suppressed in conservation agendas despite efforts to the contrary (Bennett et al. 2017; Brown 2014; Rodriguez 2017; West 2016). Most frequently IPLCs have been and continue to be criminalized because of conservation initiatives, especially those that favor ecocentric approaches to conservation (Matulis and Moyer 2017; Tauli Corpuz 2016). These practices, coupled with longstanding social, political, ecological marginalization, have left historical legacies in the very same landscapes - processes which have either explicitly or implicitly sought to erode, displace, or destroy indigenous knowledges (Li 2014; West, Igoe and Brockington 2006). Moreover, external drivers such as shifts in political regimes and their instability, urbanization, ecosystem degradation, and the dominance of global financial markets, destabilize efforts to seek and pursue conservation outcomes (Ostrom 2010; Wyborn and Bixler 2013).

Despite these hurdles, we consider biocentric and relational approaches as especially relevant for IFLs, the majority of which have historically been, or are still, stewarded by IPLCs, and the majority of which are also key targets for environmental governance and policy. An estimated one billion people rely on forests for their livelihoods and well-being, including 200 million Indigenous Peoples (Chao 2012). While IPLCs have secure land tenure on 1.3 billion acres (526 million hectares) globally, they live on and manage much more. More than 5,000 distinct Indigenous nations, 72 countries, and 30 million Indigenous Peoples currently exist, and the recognition of the role IPLCs play in conservation has been steadily growing (Lightfoot 2016; Marion Suiseeya and Zanotti 2019). For example, in Brazil alone, Indigenous Peoples live in and around one million $\mathrm{km}^{2}$ of federally recognized Indigenous Lands which serve as key conservation areas in the face of the extractive economies that predominantly surround these areas (Schwartzman and Zimmerman 2005). This seems especially relevant as we see declining IFLs worldwide. Indigenous and community owned land now represents $25.6 \%$ of the global land area, including about "40\% of all terrestrial protected areas and ecologically intact landscapes" including boreal and tropical primary forests (Garnett et al. 2018: 369). This points to the ongoing and central role IPLCs play in conservation, despite the uneven or lack of benefits that they garner from conservation initiatives. It also points to the critical need to evaluate how and in what ways to better integrate new approaches in IFL conservation initiatives. In this article we use political ecology as a frame to (1) evaluate conservation success and (2) establish and analyze case studies reflective of diverse approaches to large intact landscape conservation.

\section{Methods}

We conducted a scoping literature review to identify and characterize conservation initiatives within ILFs. The search took place in two parts; an initial theoretical review, followed by an investigation of empirical case studies. The search began in February 2017 using search terms such as but not limited to: "conservation of large intact forests", "large intact ecosystem conservation", "community-based conservation", "Indigenous Peoples and local communities", and "community managed conservation" in JSTOR and Web of Science. This produced a significant number of results which through a content analysis we identified theoretical approaches in the articles and from there highlighted three dominant approaches that have been applied to IPLCs in IFLs especially in conservation contexts: community-based forest principles (Berkes 2007), common pool resource design principles (Ostrom 1990), and adaptive capacity (Armitage et al. 2012). We then identified key terminology used in these theoretical frameworks, such as "common pool resource management", "nestedness" and "adaptive capacity" to refine our search terms for a second search in June 2017. This time we focused on selecting empirical case studies within the past 15 years that evaluate and define success in situations of IPLCs and large intact landscape conservation. These case studies were analyzed using political ecology's attentiveness to the following domains: identity, scale, power, and institutions. We further evaluated whether the cases used Berkes', Ostrom's or Armitage et al.'s framework or a close variant, and what these works revealed about applications of conservation management and therefore conservation outcomes in a variety of contexts (Table 2). Our objective was to identify case studies that covered a range of geographical, ecological and political contexts to identify characteristics of conservation success that transgress these factors and that may benefit future community conservation strategies within IFLs.

Ostrom's (1990) renowned work and associated research program on common pool resource management identifies eight 'design principles' for 'voluntary self-governed cooperative institutions' to create 
successful conservation. Because state-based or market-based initiatives alone have not been particularly successful at common pool resource management and governance, Ostrom (1990) suggests that "voluntary involvement of self-governed cooperative institutions" is one pathway to natural resource management dilemmas. These principles include clearly defined common pool resources, effective rules, monitors and conflict resolution mechanisms and self-determination of the community recognized by higher level authorities (Ostrom 1990). Agrawal (2014) and others (Agrawal et al. 2013; Cox et al. 2016) build on this theory to accommodate in the implementation changes in community behavior, informal versus formal community institution organization, cooperation vs. individual rationality - which they propose are necessary internal characteristics of the community conservation system.

\begin{tabular}{|c|c|c|c|}
\hline Creator & Ostrom 1990, 2009 & Berkes 2007 & Armitage et al. 2012 \\
\hline Model & $\begin{array}{l}\text { Common Pool Resource } \\
\text { Management in multiscalar } \\
\text { contexts }\end{array}$ & $\begin{array}{l}\text { Community Based } \\
\text { Conservation in a global world }\end{array}$ & $\begin{array}{l}\text { Adaptive Capacity in the } \\
\text { Anthropocene }\end{array}$ \\
\hline Application & $\begin{array}{l}8 \text { Design Principles: } \\
\text { • Clear boundaries } \\
\text { - Match rules governing use } \\
\text { to local needs/conditions } \\
\text { • Effective and appropriate } \\
\text { rules } \\
\text { - Rule-making rights } \\
\text { respected by outside } \\
\text { actors } \\
\text { - Monitoring behavior } \\
\text { - Graduated sanctions for } \\
\text { violation } \\
\text { - Conflict resolution } \\
\text { mechanisms } \\
\text { • Nested governing } \\
\text { responsibility from the } \\
\text { bottom-up }\end{array}$ & $\begin{array}{l}\text { Diagnostic Questions: } \\
\text { • Commons basics; } \\
\text { exclusion, subtractability } \\
\text { - Sustainable commons; } \\
\text { boundaries, rules, } \\
\text { monitoring } \\
\text { • Institutional linkages; } \\
\text { nestedness, horizontal and } \\
\text { vertical linkages } \\
\text { • Strengthening community- } \\
\text { based conservation; } \\
\text { capacity building, trust } \\
\text { building, mutual learning }\end{array}$ & $\begin{array}{l}\text { Ideal Conditions: } \\
\text { - Importance of fit and scale } \\
\text { - Fostering adaptiveness, } \\
\text { flexibility and learning } \\
\text { - Coproduction knowledge } \\
\text { from diverse sources } \\
\text { - Emergence of new actors } \\
\text { and roles in governance } \\
\text { - Expectation of } \\
\text { accountability and } \\
\text { legitimacy }\end{array}$ \\
\hline
\end{tabular}

Table 2: Common approaches to human-environmental systems or relationships.

Berkes (2007) advocates for an integrated and complex systems approach to community-based conservation that can consider multiple objectives, actors and goals at once. To do so, he argues for the use of cross and trans-disciplinary approaches to conservation (e.g. a complexity perspective) to attend to multiple, even divergent perspectives and scales, reliance on partnerships and deliberations for decision-making and governance, and to draw from common findings to "develop diagnostic tools." Similar diagnoses can identify where it is possible to transfer lessons on conservation between IFLs even though each case evolves within a unique context that makes specific solutions or conservation approaches untransferable. In particular, Berkes (2007: 15190) found that collaborative conservation that "takes local priorities and objectives, as well as the extralocal ones, into account requires systematic, multiparty interaction."

Similar conditions for adaptive co-management have been proposed, which that can result in conservation outcomes. For example, Armitage et al. noted the following conditions of governance: 
(1) recognition of the importance of fit and scale; (2) fostering adaptiveness, flexibility, and learning; (3) coproducing knowledge from diverse sources; (4) understanding the emergence of new actors and their roles in governance; and (5) changing expectations about accountability and legitimacy. (2012: 248)

Like Berkes (2007) and Ostrom (1990, 2009, 2010), Armitage et al. (2012; also see Armitage et al. 2009) addresses the underlying conditions for successful governance that may lead to desired conservation outcomes. Thus, for Armitage et al. the goal is to promote conditions that support adaptive co-management, for Berkes (2007) the goal is community-based conservation, and for Ostrom, the goal is common-pool resource management.

Using these theories as a base, we identified theoretical and empirical literature cited in those works or works which build on these models. We specifically focused on research aimed at defining successful conservation, and the indicators and criteria used to evaluate management or governance outcomes. Emergent themes that cut across many of the cases and aligned with political ecological concerns included: identities, power, types of knowledge, multi-scalar governance systems, justice and rights, and heterogenous actors. The identified themes were used as additional search terms (e.g. common pool resource management, multi-level governance) to generate a list of case studies of IPLC managed IFL conservation.

We made an attempt to provide a global sampling of IFL conservation cases to account for the broad scope of community types, cultural diversity, management practices, political and social contexts, and variance in ecosystems, although the primary focus was forest landscapes. Long-standing projects were prioritized over recent conservation management as it was assumed a longer history would allow for better evaluation of conservation success or failure. Specifically, cases were chosen because they identified outcome goals and evaluated success (or failure) of the conservation management strategy. These outcomes and definitions or characteristics of success were compared across the case studies and against the dominant theoretical frameworks to identify commonalities of success. We also compared outcomes and definitions reported in the cases to different theoretical approaches to conservation.

\section{Biocentric approaches and IFL conservation}

Analyzing case studies across a broad geographical, political and ecological range allowed us to delve into the different approaches to conservation and their impacts on the conservation features of IFLs. Boreal forest conservation was addressed in case studies from the northern hemisphere. Berkes and Davidson-Hunt (2006) and Wyborn and Bixler (2013) identify issues in multi-level governance, and a divergence of interests within community and governmental stakeholders in Canada, while Hausner et al. (2012) focuses on nestedness and self-organization in Norwegian contexts. Elbadkidze et al. (2010) compared examples across Sweden and Russia to evaluate the themes of multi-level governance and nestedness, yet each case study has unique outcomes and definitions of success. In South America, tropical forest case studies in Peru and Ecuador by Naughton-Treves et al. (2006) identify external factors as key to conservation success (or failure), while examples in Bolivia (Crawford and Mourato 2011) and Brazil (Zimmerman et al. 2001; Zanotti 2009) primarily focus on internal community engagement and cooperation. The four themes detailed below provide key insights on the tensions and synergies for the future of conservation initiatives as they correspond with dominant frameworks for evaluating and formulating co-managed landscapes in IFLs.

\section{IPLCs as actors and beneficiaries of conservation}

Indigenous Peoples and Local Communities should be considered primary actors in conservation, and not just beneficiaries of conservation initiatives (Marion Suiseeya and Zanotti 2019). Political ecologists have often found that more powerful actors define local users as "bad" rational actors that degrade landscapes and thus should have limited access to formulating conservation agendas (Berkes 2004). In our case, we found that there would be a benefit to shifting away from a bad actor model in IFL conservation. There is a high overlap of interest between IPLCs and conservationists, especially given that addressing large-scale external threats to 
forests is frequently a high priority for both. Although alliances between IPLCs and conservationists are not always straightforward, these collaborations, if linkages are managed well, can have tremendous importance for achieving outcomes that meet biodiversity and IPLC goals (Naughton-Treves et al. 2003; Peres and Zimmerman 2001; Schwartzman and Zimmerman, 2005). Ostrom (1990), for example, considers community buy-in to be an important factor in conservation success or failure. Considering IPLCs as critical actors allows the creation of rules and regulations that can be tailored to local governance priorities and therefore enable appropriate implementation, which Ostrom and others (Agrawal 2014; Lejano and de Castro 2014; Ostrom et al. 1999) consider necessary for successful community conservation management outcomes.

For example, Naughton Treves et al. (2006) reviewed case studies from 15 large (over 10,000 ha) forest protected areas across Ecuador and Peru, to examine how lack of attention to IPLC roles within official protected area designations influenced the effectiveness of conservation efforts and resulted in ongoing tensions. They found that protected areas legally designated for strict protection across Ecuador and Peru increased by 56\% between 1986 and 2006. These expansions, motivated by desire to protect critical habitat and watersheds, are often enlarged without consulting or collecting data regarding local land use (see also Peres and Zimmerman 2001). The ensuing conflicts between conservation versus economic development, ownership versus management, legal use versus illicit use, and rules versus enforcement prevail throughout the 15 protected areas in Naughton Treves et al.'s (2006) study and have been an ongoing source of struggle since.

In Naughton Treves et al.'s 2006 review, all 15 cases showed that contrasting notions of the benefits of conservation and ownership and land rights figure prominently in the ways communities' engage with conservation. While protected area creation resulted in conflict with some communities, contradictory responses occurred in others. For example, authors report, "in the Peruvian Amazon, a portion of the transitory Tambopata Candamo Reserve Zone was excised in 2000 in response to residents' demands to be 'liberated' from the reserve" (Naughton Treves et al. 2006: 36). In the Manu Biosphere Reserve, Indigenous communities and other "longterm residents petitioned to have their land included in the protected areas, hoping that such action would hasten investments in sustainable development and guard the area against incursions" from in-migrants (NaughtonTreves et al. 2006: 36). The authors find that these inconsistencies between land ownership and management lead managers to practice "pragmatic ambiguity" over resource use to avoid conflict and to build local alliances (Naughton Treves et al. 2006: 40-41).

This suggests a need to include the appropriate managerial and institutional infrastructure to carry out new conservation norms. Results from interviews with Ecuadorian conservationists also showed a mismatch between legal status, management, and extractive resource use in protected areas (Naughton-Treves et al. 2006: 40). In this case, Ecuadorian conservationists were interested in revising Ecuadorian national law to acknowledge different land rights and property claims inside protected areas to acknowledge resident use (Naughton-Treves et al. 2006: 40) The hope was that legalizing human presence would improve the likelihood of sustainable and regulated land uses. Unfortunately, this was abandoned by the Ecuadorian Congress because it raised such contention over land rights and property claims (Naughton-Treves et al. 2006: 40). In this case, residents were the first to see that existing patterns are not sustainable (see also Holt 2005), and protests occurred when IPLCs were not consulted regarding the creation of protected areas. Overall, efforts that start with negotiations at a local level and then move up to the national level for ratification, where applicable, appear to work better than top-down initiatives.

In the examples explored by Naughton-Treves et al. (2006), IPLCs are best considered beneficiaries rather than actors in conservation. Thus, there is a need to establish appropriate institutions that consider the input of actors at all levels and that promote management to avoid upset, conflict, and negative outcomes both in terms of human well-being and biodiversity conservation. Other studies that support this include the work of Berkes and Davidson-Hunt (2006), Elbadkidze et al. (2010) and Wyborn and Bixler (2013). Considering IPLCs as central actors in the conservation management process despite potentially conflicting goals between and among vested parties can and has been shown to have positive results (Matulis and Moyer 2017; Rodriguez 2017). 


\section{Knowledge integration and co-production}

Political ecologists demonstrate how blaming local users as drivers of environmental degradation results in behavioral and institutional practices and discourses that devalue their knowledge systems and craft those systems as deficient, partial, or illogical (Robbins 2011). Tension between epistemological and ontological foundations of ecological and conservation management approaches have been identified as influencing the outcomes of conservation (Ostrom 2010; Armitage et al. 2012; Sullivan 2017). Similarly, Berkes (2004) details the benefits of including multiple perspectives and knowledges to develop a transdisciplinary conservation science. Brown (2003) alternately suggests fusion knowledge - a combination of traditional and scientific - to be the most useful in developing locally appropriate biodiversity management. With multiple stakeholder interests involved, the incorporation of diverse knowledges, primarily from IPLCs but also different academic disciplines and policy fields is necessary to create conservation solutions within complex systems (Armitage et al. 2012; Caillon et al. 2017; Rodriguez 2017; Tengö et al. 2014).

Including IPLC experiences and knowledges can provide new ways of approaching, evaluating, measuring, and analyzing conservation to create synergies and complementarities (Armitage et al. 2012: 249; Tengö et al. 2014). From the landmark 1988 Declaration of Belém, which was one of the first documents to recognize the value of indigenous knowledges to the recognition of Indigenous Peoples rights and participation as critical to the protection of forests and addressing climate change at the 2017 United Nations Framework Convention on Climate Change held in Bonn, Germany, sites of global environmental governance have shown to be critical spaces that recognize the role of IPLCs. Several international governing bodies and regions have also recognized indigenous knowledges, rights, or leadership as critical to addressing environmental change, including the Convention of Biological Diversity and the Intergovernmental Science-Policy Platform on Biodiversity and Ecosystem Services (IPBES) (Tengö et al. 2014; Whitter et al. 2015).

The fact that IPLCs often have longstanding relationships with their landscapes, manage land and resources collectively, and depend (sometimes solely) on healthy ecosystems for their livelihoods, survival, and a good life improves chances of sustainable use, particularly for resources like wildlife (Berkes 2007; Chao 2012). IPLCs have coexisted with ecological cycles over extended periods of time without depleting natural resources, evidenced by agricultural practices including agroforestry, swidden cultivation, home gardens and pastoralism which increase nutrient cycling and vegetation productivity, reduce soil erosion, and support higher biodiversity (Berkes and Davidson-Hunt 2006; Cranford and Mourato 2011). Moreover, much research has shown how IPLC knowledge systems are longitudinal repositories of ways of being that adapt and respond to changing and unpredictable conditions (Gómez-Baggethun, Corbera and Reyes-García 2013). Others point to IPLCs as key stewards of biodiversity and retention of forest cover, both of which are key to maintaining critical ecosystem services, relational values, and addressing the effects of climate change (Caillon et al. 2017; Chao 2012; Davidson-Hunt 2006; Tengö et al. 2014; Wyborn and Bixler 2013).

With the remaining IFLs often being remote and/or isolated (Potapov et al. 2008), local community or Indigenous residents' knowledge of these areas is critical to IFL conservation. Community forest management include sacred groves, managed fallows, selective cultivation, traditional fire ecology and other collective resource use and decision-making strategies that protect and enhance ecosystem services (Berkes and DavidsonHunt 2006; Hawken 2017; McGregor 2005). Thus, many scholars suggest we need to create a more inclusive conservation where different knowledges are honored, a good life is promoted, and the co-production of knowledge can improve conservation measures through: planning tools, participation and buy-in in conservation efforts thus improving trust and transparency, assessing socio-cultural and ecological impacts to conservation, and prioritizing rights and justice in the process (Kaplan-Hallam and Bennett 2018: 307).

Berkes and Davidson-Hunt (2006) detail the interface and tensions between traditional ecological knowledge and management systems in Canadian boreal forest conservation, demonstrating the negative conservation and community outcomes of dismissing IPLC knowledges. Canada's boreal forest covers 6 million $\mathrm{km}^{2}$ (58\% of Canada) containing 90\% of Canada's remaining large intact forests (Berkes and Davidson-Hunt 2006: 37). Most forest management strategies across this ecosystem strive "to obtain a single dominant value from a given landscape" (Berkes and Davidson-Hunt 2006: 43). For example, protected areas aim to "maximize conservation, while forest lands are managed to maximize timber production" (Berkes and Davidson-Hunt 
2006: 43). Authors argue neither strategy appears to be effective at supporting livelihoods or conserving biodiversity. Cree, Anishnaabe (Ojibwa) and Dene (Athapascan) First Nation community lifeways and local economies rely on hunting, fishing, small-scale agriculture, and gathering medicinal plants, maple sugar, and craft products from the Boreal forest (Berkes and Davidson Hunt 2006: 37-38). Many traditional systems of forest use maintain patterns of resource use that facilitate the continued renewal of ecosystems and biodiversity, which has gone unrecognized in some forest management strategies.

Examining the context of the Anishnaabe Peoples of Shoal Lake in Northwestern Ontario and Manitoba (Iskatewizaagegan No 39 Independent First Nation), Berkes and Davidson-Hunt (2006: 38) find the current practice is to separate ecosystem management into areas of intensive use and protected areas without taking into account Anishnaabe world-views or management strategies. This is problematic because Anishnaabe Peoples value all species, and place humans as part of ecosystems, allowing for dynamism and modification so long as the ecosystems continue to produce gifts (Berkes and Davidson-Hunt 2006: 43; Berkes et al. 1998). Anishnaabe peoples have the responsibility of maintaining these gifts from the Creator, and in turn, if gifts are harmed, this can lead to individual or community level consequences (Berkes and Davidson-Hunt 2006: 42). In this context, the landscape can be modified by humans, e.g. with small fires for swidden agriculture to influence succession and productivity, but not in scales large enough so that ecological processes cease. Anishnaabe principles thus consider that "every habitat and species have a reason to be there, known or unknown, and for that reason the full suite of plant species should be maintained into the future" (Berkes and Davidson-Hunt 2006: 43). This highlights key tensions between dominant approaches to large-scale landscape management in boreal forest environments versus learning from and integrating local and indigenous knowledges across scales in planning, processual, and implementation phases of conservation measures.

For example, if we apply Anishnaabe concepts to current dominant approaches in multifunctional landscape management, we see how co-production of knowledge can reinforce management practices that support biocultural diversity as connected to the "functional properties of a habitat or species", understanding all the connections may not currently be known (Berkes and Davidson-Hunt 2006: 43). Prioritizing coproduction in turn may provide opportunities to integrate indigenous and scientific knowledges to develop a more complete 'fusion knowledge' and therefore effective adaptive management strategies (see Brown 2003). This suggests that integrating intact IPLC knowledge systems and perspectives into large-scale management practices, especially IFLs, can both help to achieve as well as broaden conservation objectives while addressing local livelihood needs.

By addressing conservation of large intact landscapes with an approach based on scientific pluralism in conservation practice, instead of a scientific imperialism perspective, we can make use of multiple theories, disciplines and epistemologies (Olsson et al. 2015). Rather than attempting to develop theories which encompass extremely diverse peoples, politics and ecosystems of IFLs, scientific pluralism, weaving indigenous ecological knowledges within these processes can help determine successes and adaptive strategies in different social and ecological contexts.

\section{Heterogenous communities and equity impacts}

Identifying how and in what way communities are defined is a key principle in evaluating the success of conservation, especially with IFLs. Political ecologists and especially feminist political ecologists have added to this literature theoretically, prioritizing heterogenous and intersectional identities, micro-scales of analysis, and examinations of justice, equity, and rights (Elmhirst 2011; Mollet and Faria 2013). Political ecologists and other scholars also have drawn attention to the problematic category of "community" as the scalar unit from which to set conservation-related goals, especially when community is defined from a top-down, rather than bottom-up approach (Agrawal 2014). Ostrom's design principles rely on a "voluntary self-governed cooperative institution" which has been extrapolated to mean "community." An emerging consensus that "community" involvement is necessary for successful conservation efforts has developed, yet conservation success has been uneven across different community-informed conservation initiatives. In fact, some practitioners are concerned community conservation is becoming a 'blueprint solution' to its own detriment (Berkes 2007). For example, Barrett et al. (2001: 497) states "the current fashion for community-based natural resource management 
overemphasizes the place of local communities in tropical conservation efforts, much as the previous top-down model underestimated it." Similarly, Berkes (2007: 15188) and Armitage et al. (2012) suggest that "community conservation" is not a panacea that can provide solutions in all situations and contexts.

A lack of recognition of both how communities are defined as well as the intricate workings of a "community" hinder the ability to accurately assess and inform how equity or justice operates in on-the-ground action. While communities may appear from the top down to have communal goals, values and boundaries, individual community members' incentives, socio-economic status, equity and other factors may vary, influencing social institutions, leadership, capacity building, and ability to achieve social justice (Dawson et al. 2018). More specifically, the diversity within a community influences trust and perceptions of fairness, buy-in to the conservation work and resource management goals, participation in conservation effort as well as varied social impacts of conservation (Dawson et al. 2018). Thus, this fuzziness around the concept of community can limit or detract from implementing conservation as well as limit our understandings of achieving outcomes that uphold indigenous and human rights and justice concerns.

Within our review of diverse models of conservation within IFLs, many of the successful case studies we examined consider communities as heterogeneous and investigated what factors motivated individuals to participate in community-based conservation. Attention to dominant conservation policy, particularly who is being affected at what stage, is necessary to effectively enact IFL conservation. For example, one case study linked success to greater age and time spent living in the community or conservation area, participation in conservation activities, and reliance on ecological resources for livelihoods. Internal motivation within the community also varies, but generally seems to rely heavily on relational values, social acceptance of proper management and practice, and cultural and livelihood incentives to participate (Berkes 2007; Chan et al. 2016; Hambler and Canney 2013; Hausner et al 2012; Wyborn and Bixler 2013). In another example, a case study found community members whose livelihoods were reliant on ecological resources were highly involved in community conservation initiatives, yet older members who had spent more time living in the community were also highly engaged even if they no longer could continue customary harvesting practices. In yet another case study, Zimmerman et al. (2001: 20) found that conservation initiatives with Mebêngôkre -Kayapó Peoples in Brazil were successful in part because their work aligned with characteristics that corresponded with Ostrom's common-pool design principles: namely, involvement of local users and institutions alongside new communityconservation partnerships. Similarly, Zanotti (2009) found among the Mebêngôkre-Kayapó Peoples (Brazil) a high level of buy-in from diverse individuals, participation from the local community, and distributed benefits to have the most success with retaining community-conservation program collaborations and relationships. However, this author also found these relationships are stressed when scaled out to inter-community and territory-wide initiatives where predatory external drivers of change destabilize social institutions, indigenous values, and ecological integrity. One case study in Sierra Leone (Larson et al. 2016) also found conflict between different community groups engaged in a communal, community-based wildlife conservation project. Here, while all groups agreed with the mission of community-controlled conservation, the benefits were perceived as unequal as the distribution of those benefits between and among different community members were uneven.

Hausner et al.'s (2012) case study of Sami Pastoralist in Finnmark Norway, is an illustrative example of why IFL conservation should prioritize attentiveness to the heterogeneity of communities and associated equity and rights impacts. While not specifically a case of an ILF landscape, in answering Ostrom's question "Why do some resource users self-organize to manage common pool resources sustainably and others do not?" Hausner et al.'s (2012: e51187) work illustrates why it is dangerous to not pay attention to community heterogeneity and how sub-communities impact conservation management success. This case brings to light structural and social components of community-based management, such as autonomy, tenure and resource security, seasonality, flexibility, homogeneity, nestedness, and conflict resolution that impact conservation outcomes. These can be scaled to represent applicable issues and contexts in IFL conservation.

In this case, Sami pastoralists customarily self-organized into sub-community groups called siidas which act as both social and economic groups, managing reindeer herds on common pastures. In the summer each siida has "exclusive rights" to a pasture yet in the winter as resource availability becomes scarcer, multiple siidas must manage a few large pastures together (Hausner et al. 2012: e51187). The 1978 Reindeer Husbandry Act defined "winter pastures as common land", and has made both governmental regulated and self-organized 
conflict resolution difficult (Hausner et al. 2012: e51187). Before this policy enactment, winter tenures were organized based on customary tradition, and conflict was resolved through siida isit (informal leaders). According to Hausner et al. (2012: e51187), the 1978 Act opened up the winter pastures, whereby some pastoralists attempt to continue following traditional boundaries while others disregard tradition and treat pastures as open. Because the rules and rights of traditional siida are not formalized, governmental reindeer police have no influence, and informally reporting other siidas to the police leads to social retribution (Hausner et al. 2012). This input of governmental regulation has shifted the conflict resolution system to one determined by power, which equates to herd size (Hausner et al. 2012). When asked what may improve sustainable management, Sami pastoralists identified either (1) formal siida tenure rules and a sanctioning mechanism by an impartial authority or (2) more autonomy for the siida institutions to create an informal rule system. The gap between informal and formal rules and rights that emerged after the 1978 Act, left the system vulnerable to conflict over inequitable distribution of resources. These emerging conflicts are exacerbated by other factors and can have cascading effects on conservation management and their associated outcomes (Hausner et al. 2012).

Ostrom (1990, 2009) suggested the outcomes that result from self-organizing groups depend on the degree of trust and their ability to negotiate and cooperate on a larger scale. For example, with plentiful resources in summer, the spatial extent of pasture has no influence on achieving sustainable management, which Hausner et al. (2012) find is a result of the local siida institution managing social and ecological impacts. In this case, internal trust in siidas is strong because of long family histories of trust, equitable distribution of resources, and collaboration. However, lack of trust between individual siidas managing shared pastures together in winter seasons created conflict. Even though all pastoralists involved agree on the need for sustainable management, in this season, extensive winter pastures have less sustainable outcomes than smaller ones. Hausner et al. (2012) identify the cause of failure as an increase in the heterogeneity of siidas, inequitable outcomes, a lack of trust and a lack of adequate conflict resolution mechanisms. Similar internal community factors may be important when applying this to IFL landscapes. Thus, while heterogeneity per se does not increase conservation outcomes, recognition of heterogeneity and the need for equitable impacts can draw attention to how certain outcomes are either met or strained, and the importance of trust across different polycentric systems.

Further, dissecting the complexity, diversity, dynamism and heterogeneity of conservation initiatives, the Hausner et al. (2012) case also highlights a need for conservation management strategies to adapt to changing community composition, governance structures, and ecological settings. While Armitage et al. (2012: 248) points out that "it is not appropriate to blithely suggest best practices based on experiences in other places", Berkes (2007) suggests diagnostic questions can be useful to identify opportunities where applying similar treatments and solutions from one case to hopefully mimic conservation success in another case. The context specificity of each case and the inability to accurately apply solutions across them is echoed by Brosius (1997) and Zerner (2000). While Ostrom's common pool resource management design principles remain a commonly used theory in case study analysis, we propose an important additional diagnostic question may be identifying where a 'community' does or does not equate to a 'voluntary self-governed cooperative institution', and whether it can bring about equitable outcomes. Furthermore, the development of diagnostic questions of scaling community-based conservation and adaptive strategies beyond their original scope in terms of community definitions, landscape and the political context may be beneficial to addressing multi-stakeholder needs, identifying equity outcomes, sharing strategies, and obtaining successful outcomes in IFL conservation.

\section{IPLC management and governance in polycentric systems}

Case studies highlight that external forces and actors as well as external systems are a major influence in conservation. Political ecology's attentiveness to structures of power, informal and formal institutions, and hegemonic discursive forms are relevant in uncovering how and in what way biocentric models can move toward more inclusive conservation within IFLs (Berkes 2007; Gavin et al. 2015). Berkes (2007: 15188) suggests that conservation is a "complex system problem", with the natural environment, social structure, and political systems involving hierarchically organized subsystems, each with associated issues of scale, diversity, 
complexity, and uncertainty. Essentially the question of "why should a federal government or resource extraction company decentralize and give up control of a region or resources to a local community group, what is in it for them?" has to be addressed and answered. Community-based management is often not "worthwhile" to these stakeholders but addressing this is very context-specific. This is an especially relevant domain for large IFL conservation practice, as these landscapes often encompass multiple communities, jurisdictional units, and political interests (Betts et al. 2017; Heino et al. 2015; Wyborn and Bixler 2013).

Theoretically, while Ostrom's approach demonstrates a clear sense of how defined resource users, governing institutions and social norms contribute to conservation outcomes, it is unclear how interfacing multiple scales of action among external actors within power asymmetries may influence these outcomes in various contexts. Her later work on polycentric systems attempts to account for this, where nested systems mitigate risk, distribute power, and increase redundancy to reduce vulnerability (Gruby and Basurto 2013; Ostrom 2010). Finding where interests and positions align or diverge among diverse individuals and stakeholders both internal and external to the community is necessary to ensure proper communication, preparation, and conflict resolution for the long-term success of any project, and this is more complex with the number of stakeholders involved and the variation in each stakeholders' interests and position (Ostrom 2010). This arrangement only works when every community or stakeholder receives something that makes the community-based environmental management worthwhile, and affects what type of management is chosen and how it is organized, enforced and evaluated in polycentric contexts (Ostrom 2010; Sattler et al. 2006: 24). Multilevel cooperative governance requires 'horizontal and vertical interaction' between various state and non-state actors and a complexity perspective for conflict resolution and polycentric mutual decision making to deal with multiple objectives (Sattler et al. 2006: 24). In these types of systems communication, transparency and negotiation is needed by all parties, particularly in cases where market, state and self-governed community institutions are all trying to govern an area simultaneously with divergent outcome goals.

Many of the case studies we evaluated showed success or failure came as a result of support from, or conflict with, external stakeholders such as federal governments, resource extraction corporations or conservation groups at various levels and timelines within the conservation project (Berkes and Davidson-Hunt 2006; Cranford and Mourato 2011; Elbadkidze et al. 2013; Naughton-Treves et al. 2006). Economic and political stakeholders in many cases have very different outcome goals than local community members, and often have more monetary or influential power to exert their objectives over local community intentions. Conflicting values, goals and the power of external elements such as political instability, government regulation, and corporate resources can exacerbate ineffectiveness, failure, or empty claims of community-based conservation. In Canada's boreal forest, Berkes and Davidson-Hunt (2006) found that long-term forest ecosystem health and livelihood needs are complementary but that outcomes can be uneven given political conditions and power differentials. The traditional ecosystem-based management systems have been used to ensure forest succession management, non-timber forest product growth and multiple species management. However, authors show that the province of Ontario prioritizes dividing areas between intensive timber areas and strictly protected areas, both drastically altering the large intact forest ecosystem and reducing conservation and development outcomes. These authors showcase how even within a relatively stable political environment and nested governance system, varied objectives and power imbalance between community and government can impact the ability of a community to successfully manage conservation. This leads back to the importance of integrating indigenous knowledges systems and community-decision-making into forest management.

In many case studies, conservation and IPLCs do not have aligned interests (outcome goals) but more often have aligned positions (the process to reach their outcome goals) (Naughton-Treves et al. 2006; Schwartzman and Zimmerman 2005). The divergence in outcome goals can affect partnerships between formal and informal institutions generally deemed to be partners. This is especially important in areas such as IFLs, where Indigenous Peoples do not always have secure land-tenure or control of the natural resources used for community livelihoods. Biodiversity conservation, livelihood needs, and priorities for a good life are or should be complementary goals but these objectives rarely coexist as equals, and instead one objective or the other dominates (Brown 2003).

For example, Naughton-Treves et al. (2006) found that designating certain areas in Peru and Ecuador as protected areas created conflict with and between groups of IPLCs, conservationists, and government 
enforcement whose roles and ability to use various areas of land and resources had changed. Conservationists may have the goal of protecting biodiversity whereas local peoples want to protect food sources. Protected area status is sought for different reasons (Redford and Stearman 1993) and once protected area management processes are in place, conflict can ensue as a result of mismatched outcomes, e.g. local peoples who continue to hunt certain species within the protected area for their livelihood needs may conflict with the conservationist outcome of protecting biodiversity within the protected area.

Similarly, Wyborn and Bixler's (2013) study of three semi-autonomous nested cases in the Rocky Mountains demonstrate how power in multi-level governance contexts plays a significant role in conservation outcomes. First, the Yellowstone to Yukon (Y2Y), is a supra-regional territory encompassing "five US states, two Canadian provinces, two Canadian territories, and the traditional territories of 31 First Nations groups", that focuses on science, stewardship, and advocacy (Wyborn and Bixler 2013: 61). Second, The Round Table on the Crown of the Continent is a regional collaboration crossing the Canadian/US border that works in dialogue to build and maintain relationships with regionally dispersed actors. Third, The Blackfoot Challenge is a local initiative that works across multiple scales to connect landowners, agencies and land trusts to "collaboratively direct conservation efforts within their watershed" (Wyborn and Bixler 2013: 62). While working at different scales, all three draw on sense-of-place and concern for the future to promote collaboration, and they depend on philanthropic community and government grants (Wyborn and Bixler 2013: 60). Authors find that while Y2Y is strongly supported by the scientific community and by geographically removed urban constituencies who support large carnivore conservation, working collaboratively and incorporating diverse perspectives is still difficult to organize. In this case, the supra-regional collaboration risks homogenizing local actors and place-based communities, thereby missing the potential for diverse inputs to the overarching vision, plan and outcome. One key informant states, "People working to sustain the crown at whatever level are connected to a common landscape but they are not connected to each other" (Wyborn and Bixler 2013: 62). The Crown tries to bridge this by creating a space for conversation between the many people involved in the place to promote a "holistic understanding of the connections between communities, conservation and culture" and the larger social, political and ecological landscapes (Wyborn and Bixler 2013: 62). The authors thus conclude that in these large landscape conservation practices, the challenge from the local level is continuing to find linkages to the large-scale mission without undermining local rights or relational values.

To adequately address conservation at multiple scales, conservation initiatives need solid networks to take into account diverse interests and actors across scales. Collaboration is difficult between scales as questions remain in nested governance situations of who should undertake what activities at which levels, and how institutions should work collectively (Wyborn and Bixler 2013: 65). Management strategies across "jurisdictional boundaries and fragmented policies" mean tension between these scales of operation, despite several initiatives seeking to work across them (Wyborn and Bixler 2013: 63). Authors suggest that focusing on local participation, sustainable natural and human communities, and voluntary consent and compliance over enforcement can help. However, prioritizing cross-scale interactions are imperative for achieving shared social and ecological outcomes. While we recognize the importance of IPLC management and governance strategies at the local level, we caution against the sole focus on the "lowest appropriate level" of governance. Instead, attention to polycentric systems of management, and the power relationships they bring and justice issues they raise, are critical.

\section{Conclusion}

Our findings demonstrate how a political ecology framework can assist in analyzing the theoretical and policy concerns of integrating IPLC management in the conservation of IFLs. Our analysis of case studies found four priority areas for the future of IFL conservation. We recommend prioritizing IPLCs as actors and beneficiaries of conservation. Without considering internal and external drivers of change or engaging IPLCs in conservation efforts, conservation efforts will not be as effective in areas where IFLs exist. We also show that longstanding community engagement and investment in large intact landscapes aligns with how these spaces have value to local communities and worldviews. Exclusion of peoples from conservation agendas in large intact landscapes has implications for rights, justice, equity, and a good life, as seen in the widespread failure of fortress conservation efforts in the 1980s and 1990s (Berkes 2007; Brondizio and Le Tourneau 2016; 
Campbell and Vainio Mattila 2003; Kareiva and Marvier 2012; Tengö et al. 2017). Thus, we recommend attentiveness to diverse values, power relationships, knowledge integration, and co-production for conservation design (Kaplan-Hallam and Bennett 2018).

As Wyborn and Bixler (2013: 58) remind us, large scale conservation is multi-scalar and thus "functions at larger, more complex spatial, temporal and jurisdictional scales" (also see Guerrero, McAllister and Kerrie 2015; Saunders and Briggs 2002). Many IFLs cross multiple political borders and are stewarded by diverse peoples, which means that fragmentation threats, management strategies, protection type or conservation outcome may vary across the landscape itself. Thus, we suggest addressing heterogenous communities, rights concerns, and equity impacts as well as identifying procedural mechanisms in conservation initiatives that support nesting IPLC management and governance in polycentric systems. This can be beneficial to IFL conservation if attention to power at the different scales remains. The scale of common pool resources within large intact landscapes conservation inevitably leads to greater social complexity and therefore new difficulties in creating self-governed cooperative institutions that can reach agreements on appropriate goals and actions regarding common pool resource management. As threats such as large-scale resource extraction continue to increase, IFL conservation management that recognizes relations, knowledge systems, governance, power, and desired outcomes becomes all the more important.

Drawing upon a political ecological approach, our results also show there is an ongoing need to critically evaluate the cross-cutting themes of power, scale, identity, rights, and institutions both in their application to the outcomes of conservation but also to the formulation of conservation science. These are critical steps to a more collaborative and inclusive form of conservation in ILFs. IPLC place-attachments connected to nonmaterial facets of conservation, such as relational values, motivate IPLCs to continue to fight for the sustainability of these same landscapes, through different pathways. The most common avenue to pursue this goal is through fighting for the protection of environmental, indigenous and human rights, especially in times of precarity, austerity, and political upheaval (Gavin et al. 2015). Identification of spatial and temporal fits and mismatches, for example between individual and collective needs, and short and long-term gains, are also necessary conditions of conservation in large intact landscapes, to enable successful conservation regimes. Finally, we advise that it is important to continue to pay attention to the relational and epistemic values at stake, the scales at which conservation is happening, the power asymmetries involved, and the complexity of the multiple systems (Berkes 2017; Tengö et al. 2017).

\section{References}

Agrawal, A. 2014. Studying the commons, governing common-pool resource outcomes: some concluding thoughts. Environmental Science and Policy 36: 86-91.

Agrawal, B., D. Brown, G. Rao, R. Riolo, D.T. Robinson and M. Bommarito. 2013. Interactions between organizations and networks in common-pool resource governance. Environmental Science and Policy 25(C): 138-146.

Arias-Arévalo, P., B. Martín-López, and E. Gómez-Baggethun. 2017. Exploring intrinsic, instrumental, and relational values for sustainable management of social-ecological systems. Ecology and Society 22(4): 43.

Armitage, D., R. De Loë and R. Plummer. 2012. Environmental governance and its implications for conservation practice. Conservation Letters 5(4): 245-255.

Armitage, D.R., R. Plummer, F. Berkes, R.I. Arthur, A.T. Charles, I.J. Davidson-Hunt, A.P. Diduck, N.C. Doubleday, D.S. Johnson, M. Marschke, P. Mcconney, E.W. Pinkerton and E.K. Wollenberg. 2009. Adaptive co-management for social-ecological complexity. Frontiers in Ecology and the Environment 7(2): 95-102.

Barrett, C., K. Brandon, C. Gibson and H. Gjertsen. 2001. Conserving tropical biodiversity amid weak institutions. BioScience 51(6): 497-502.

Berkes, F. 2004. Rethinking community-based conservation. Conservation Biology 18(3): 621-630. 
Berkes, F. 2007. Community-based conservation in a globalized world. Proceedings of the National Academyof Sciences of the United States 104(39): 15188-15193.

Berkes, F., M. Kislalioglu, C. Folke and M. Gadgil. 1998. Mini reviews: exploring the basic ecological unit: ecosystem-like concepts in traditional societies. Ecosystems 1(5): 409-415.

Berkes, F. 2017. Environmental governance for the anthropocene? Social-ecological systems, resilience, and collaborative learning. Sustainability 9(7): 1232.

Berkes, F. and I.J. Davidson-Hunt. 2006. Biodiversity, traditional management systems and cultural landscapes: examples from the boreal forest of Canada. International Social Science Journal 58(187): 35-47.

Betts, M.G., C. Wolf, W.J. Ripple, B. Phalan, K.A. Millers, A. Duarte, S.H.M. Butchart and T. Levi. 2017. Global forest loss disproportionately erodes biodiversity in intact landscapes. Nature 547(7664): 441444.

Bennett, N.J., R. Roth, S.C. Klain, K. Chan, P. Christie, D.A. Clark, G. Cullman, D. Curran, T.J. Durbin, G. Epstein and A. Greenberg. 2017. Conservation social science: understanding and integrating human dimensions to improve conservation. Biological Conservation 205: 93-108.

Birdsey, R., and Y. Pan. 2015. Trends in management of the world's forests and impacts on carbon stocks. Forest Ecology and Management 355(1): 83-90.

Brondizio, E. and F. Le Tourneau. 2016. Environmental governance for all. Science 352(6291): 1272-1273.

Brinck, K., R. Fischer, J. Groeneveld, S. Lehmann, M. Dantas De Paula, S. Pütz, J. O. Sexton, D. Song, and A. Huth. 2017. High resolution analysis of tropical forest fragmentation and its impact on the global carbon cycle. Nature Communications 8(1): 1-6.

Brosius, J.P. 1997. Endangered forest, endangered people: environmentalist representations of indigenous knowledge. Human Ecology 25(1): 47-69.

Brosius, J.P. and D. Russell. 2003. Conservation from above: an anthropological perspective on transboundary protected areas and ecoregional planning. Journal of Sustainable Forestry 17(1): 39-66.

Brown, K. 2003. Integrating conservation and development: a case of institutional misfit. Frontiers in Ecology and the Environment 1(9): 479-487.

Brown, K. 2014. Global environmental change I: a social turn for resilience? Progress in Human Geography 38(1): 107-117.

Büscher, B. and R. Fletcher. 2020. The conservation revolution: radical ideas for saving nature beyond the Anthropocene. London: Verso.

Caillon, S., G. Cullman, B. Verschuuren and E. Sterling. 2017. Moving beyond the human-nature dichotomy through biocultural approaches: including ecological well-being in resilience indicators. Ecology and Society 22(4): 27.

Campbell, L.M. and A. Vainio-Mattila. 2003. Participatory development and community-based conservation: opportunities missed for lessons learned? Human Ecology 31(3): 417-437.

Chan, K. M. A., P. Balvanera, K. Benessaiah, M. Chapman, S. Díaz, E. Gómez-Baggethun, R. Gould, N. Hannahs, K. Jax, S. Klain, G. W. Luck, B. Martín-López, B. Muraca, B. Norton, K. Ott, U. Pascual, T. Satterfield, M. Tadaki, J. Taggart, and N. Turner. 2016. Opinion: Why protect nature? Rethinking values and the environment. Proceedings of the National Academy of Sciences 113(6): 1462-1465.

Chao, S. 2012. Forest peoples: numbers across the world. Moreton-in-Marsh, UK: Forest People's Programme.

Cote, M. and A.J. Nightingale. 2012. Resilience thinking meets social theory: situating social change in socioecological systems (SES) research. Progress in Human Geography 36(4): 475-489.

Cox, M., S. Villamayor-Tomas, G. Epstein, L. Evans, N.C. Ban, F. Fleischman, M. Nenadovic and G. GarciaLopez. 2016. Synthesizing theories of natural resource management and governance. Global Environmental Change 39: 45-56.

Cranford, M. and S. Mourato. 2011. Community conservation and a two-stage approach to payments for ecosystem services. Ecological Economics 71: 89-98. 
Dawson, N., A. Martin and F. Danielsen. 2018. Assessing equity in protected area governance: approaches to promote just and effective conservation. Conservation Letters 11(2): e12388.

Díaz, S., S. Demissew, J. Carabias, C. Joly, M. Lonsdale, N. Ash, A. Larigauderie, J.R. Adhikari, S. Arico, A. Báldi and A. Bartuska. 2015. The IPBES Conceptual Framework-connecting nature and people. Current Opinion in Environmental Sustainability 14: 1-16.

Elbakidze, M., P.K. Angelstam, C. Sandström and R. Axelsson. 2010. Multi-stakeholder collaboration in Russian and Swedish Model Forest initiatives: adaptive governance toward sustainable forest management? Ecology and Society 15(2): 14.

Elmhirst, R. 2011. Introducing new feminist political ecologies. Geoforum 42(2): 129-132.

Garnett, S., N. Burgess, J. Fa, A. Fernandez-Llamazares, Z. Molnár, C. Robinson, J.E.M. Watson, K.K. Zander, B. Austin, E.S. Brondizio, N. French Collier, T. Duncan, E. Ellis, H. Geyle, M.V. Jackson, H. Jonas, P. Malmer, B. McGowen, A. Sivongxay and I. Leiper. 2018. A spatial overview of the global importance of Indigenous lands for conservation. Nature Sustainability 1: 369-374.

Gavin, M., J. McCarter, A. Mead, F. Berkes, J. Stepp, D. Peterson and R. Tang. 2015. Defining biocultural approaches to conservation. Trends in Ecology and Evolution 30(3): 140-145.

Gómez-Baggethun, E., E. Corbera and V. Reyes-García. 2013. Traditional ecological knowledge and global environmental change: research findings and policy implications. Ecology and Society 18(4): 72.

Gruby, R. and X. Basurto. 2013. Multi-level governance for large marine commons: Politics and polycentricity in Palau's protected area network. Environmental Science and Policy 32: 260-272.

Guerrero, A., R. Mcallister and K. Wilson. 2015. Achieving cross-scale collaboration for large scale conservation Initiatives. Conservation Letters 8(2): 107-117.

Hambler, C. and S.M. Canney. 2013. Conservation. Cambridge: Cambridge University Press.

Hausner, V.H., P. Fauchald and J.L. Jernsletten. 2012. Community-based management: under what conditions do Sámi pastoralists manage pastures sustainably? PloS One 7(12): e51187.

Heino, M., M. Kummu, M. Makkonen, M. Mulligan, P.H. Verburg, M. Jalava and T.A. Räsänen. 2015. Forest loss in protected areas and intact forest landscapes: a global analysis. PloS One 10(10): e0138918.

Holt, R.P. 2005. Post-Keynesian economics and sustainable development. International Journal of Environment, Workplace and Employment 1(2): 174-186.

Holmes, G., C. Sandbrook and J.A. Fisher. 2017. Understanding conservationists' perspectives on the newconservation debate. Conservation Biology 31(2): 353-363.

Intact Forests. ND. Intact Forest Landscapes. Available at http://www.intactforests.org/

Kaplan-Hallam, M. and N. Bennett. 2018. Adaptive social impact management for conservation and environmental management. Conservation Biology 32(2): 304-314.

Kareiva, P. and M. Marvier. 2012. What is conservation science? BioScience 62(11): 962-969.

Larson, L.R., A.L. Conway, K.E. Krafte, S.M. Hernandez and J.P. Carroll. 2016. Community-based conservation as a potential source of conflict around a protected area in Sierra Leone. Environmental Conservation 43(3): 242-252.

Lejano, R.P. and F. Fernandez de Castro. 2014. Norm, network and commons: the invisible hand of community. Environmental Science and Policy 36: 73-85.

Li, T.M. 2014. Land's End: capitalist relations on an indigenous frontier. Durham: Duke University Press.

Lightfoot, S. 2016. Global indigenous politics: a subtle revolution. New York: Routledge.

Marion Suiseeya, K.R. and L. Zanotti. 2019. Making influence visible: innovating ethnography at the Paris Climate Summit. Global Environmental Politics 19(2): 38-60.

Matulis, B.S. and J.R. Moyer. 2017. Beyond inclusive conservation: the value of pluralism, the need for agonism and the case for social instrumentalism. Conservation Letters 10(3): 279-287.

McGregor, D. 2005. Traditional ecological knowledge: an Anishnabe woman's perspective. Atlantis: Critical Studies in Gender, Culture and Social Justice 29(2): 103-109. 
Mollett, S. and C. Faria. 2013. Messing with gender in feminist political ecology. Geoforum 45: 116-125.

Naughton-Treves, L., N. Alvarez-Berríos, K. Brandon, A. Bruner, M.B. Holland, C. Ponce, M. Saenz, L. Suarez and A. Treves. 2006. Expanding protected areas and incorporating human resource use: a study of 15 forest parks in Ecuador and Peru. Sustainability: Science, Practice and Policy 2(2): 32-44.

Olsson, L, A. Jerneck, H. Thoren, J. Persson and D. O'Byrne. 2015. Why resilience is unappealing to social science: theoretical and empirical investigations of the scientific use of resilience. Science Advances 1(4): e1400217.

Ostrom, E. 1990. Governing the commons: the evolution of institutions for collective action. Cambridge: Cambridge University Press.

Ostrom, E. 2009. A general framework for analyzing sustainability of social-ecological systems. Science 325(5939): 419-422.

Ostrom, E. 2010. Beyond markets and states: polycentric governance of complex economic systems. American Economic Review 100(3): 641-672.

Ostrom, E., J. Burger, C.B. Field, R.B. Norgaard and D. Policansky. 1999. Revisiting the commons: local lessons, global challenges. Science 284(5412): 278-282.

Peres, C.A. and B. Zimmerman, B. 2001. Perils in parks or parks in peril? Reconciling conservation in Amazonian reserves with and without use. Conservation Biology 15(3): 793-797.

Potapov, P., A. Yaroshenko, S. Turubanova, M. Dubinin, L. Laestadius, C. Thies, D. Aksenov, A. Egorov, Y. Yesipova, I. Glushkov and M. Karpachevskiy. 2008. Mapping the world's intact forest landscapes by remote sensing. Ecology and Society 13(2): 51.

Potapov, P., M.C. Hansen, L. Laestadius, S. Turubanova, A. Yaroshenko, C. Thies, W. Smith, I. Zhuravleva, A. Komarova, S. Minnemeyer and E. Esipova. 2017. The last frontiers of wilderness: tracking loss of intact forest landscapes from 2000 to 2013. Science Advances 3(1): e1600821.

Redford, K.H. and A.M. Stearman. 1993. Forest-dwelling native Amazonians and the conservation of biodiversity: interests in common or in collision? Conservation Biology 7(2): 248-255.

Rodriguez, I. 2017. Linking well-being with cultural revitalization for greater cognitive justice in conservation: lessons from Venezuela in Canaima National Park. Ecology and Society 22(4): 24.

Sanderson, E.W., M. Jaiteh, M.A. Levy, K.H. Redford, A.V. Wannebo and G. Woolmer. 2002. The human footprint and the last of the wild: the human footprint is a global map of human influence on the land surface, which suggests that human beings are stewards of nature, whether we like it or not. AIBS Bulletin 52(10): 891-904.

Sattler, C., B. Schröter, A. Meyer, G. Giersch, C. Meyer and B. Matzdorf. 2016. Multilevel governance in community-based environmental management: a case study comparison from Latin America. Ecology and Society 21(4): 24.

Saunders, D.A. and S.V. Briggs. 2002. Nature grows in straight lines or does she? What are the consequences of the mismatch between human-imposed linear boundaries and ecosystem boundaries? An Australian example. Landscape and Urban Planning 61 (2-4): 71-82.

Schwartzman, S. and B. Zimmerman. 2005. Conservation alliances with indigenous peoples of the Amazon. Conservation Biology 19(3): 721-727.

Sullivan, S. 2017. What's ontology got to do with it? On nature and knowledge in a political ecology of the 'green economy'. Journal of Political Ecology 24: 217-242.

Tauli Corpuz, V. 2016. Report of the special rapporteur of the Human Rights Council on the rights of Indigenous Peoples. United Nations General Assembly Seventy-first session. Item 66(a) of the provisional agenda A/71/150.

Tengö, M., E.S. Brondizio, T. Elmqvist, P. Malmer and M. Spierenburg. 2014. Connecting diverse knowledge systems for enhanced ecosystem governance: the multiple evidence base approach. Ambio 43(5): 579591. 
Tengö, M., R. Hill, P. Malmer, C.M. Raymond, M. Spierenburg, F. Danielsen, T. Elmqvist and C. Folke. 2017. Weaving knowledge systems in IPBES, CBD and beyond-lessons learned for sustainability. Current Opinion in Environmental Sustainability 26: 17-25.

Vaccaro, I., O. Beltran and P.A. Paquet. 2013. Political ecology and conservation policies: some theoretical genealogies. Journal of Political Ecology 20: 255-272.

Watson, J.E., T. Evans, O. Venter, B. Williams, A. Tulloch, C. Stewart, I. Thompson, J.C. Ray, K. Murray, A. Salazar and C. McAlpine. 2018. The exceptional value of intact forest ecosystems. Nature Ecology and Evolution 2(4): 599-610.

West, P. 2016. Dispossession and the environment: rhetoric and inequality in Papua New Guinea. New York: Columbia University Press.

West, P., J. Igoe and D. Brockington. 2006. Parks and peoples: the social impact of protected areas. Annual Review of Anthropology 35: 251-277.

Witter, R., K.R. Marion Suiseeya, R.L. Gruby, S. Hitchner, E.M. Maclin, M. Bourque and J.P. Brosius. 2015. Moments of influence in global environmental governance. Environmental Politics 24(6): 894-912.

Wyborn, C. and P.R. Bixler. 2013. Collaboration and nested environmental governance: scale dependency, scale framing and cross scale interactions in collaborative conservation. Journal of Environmental Management 123: 58-67.

Zanotti, L. 2009. Economic diversification and sustainable development: The role non-timber forest products play in the monetization of Kayapó livelihoods. Journal of Ecological Anthropology 13(1): 26-41.

Zerner, C. (ed.) 2000. People, plants, and justice: the politics of nature conservation. New York: Columbia University Press.

Zimmerman, B., C.A. Peres, J.R. Malcolm and T. Turner. 2001. Conservation and development alliances with the Kayapó of south-eastern Amazonia, a tropical forest indigenous people. Environmental Conservation 28(1): 10-22. 